\title{
Miliary granulomata in a fatal adult case of listerial meningitis
}

\author{
J. R. HENDERSON* \\ M.A., B.Sc., B.M. \\ Department of Neuropathology, \\ Institute of Psychiatry, \\ Maudsley Hospital, London, S.E.5
}

\author{
C. A. RAMSEY* \\ M.B., M.R.C.P. \\ Department of Dermatology, \\ The London Hospital, \\ London, E.1
}

Listeria monocytogenes is a Gram-positive bacillus known to cause abortion, septicaemia and meningo - encephalitis in wild and domestic animals. It was first described in laboratory guinea-pigs and rabbits by Murray, Webb \& Swann at Cambridge in 1926, and the following year shown to the causative organism in a plaguelike disease of gerbilles in South Africa (Pirie, 1927). It was this author who gave the bacterium its name.

Most workers feel that the infection is probably commoner than the number of proven cases suggests. This is because in its cultural behaviour the organism is oddly capricious, and may only grow when kept in a refrigerator for a few days. Again, it is easily decolourized on Gram staining and may have the appearance of a Gram-negative organism. Cultures that are Gram-positive on first being plated may become negative on subculture. The organism also labours under the handicap of looking like a diphtheroid contaminant, and may be rejected as such.

It is always assumed that human infection is derived from animals - but the route remains obscure, and many theories have been proposed. In man the disease is most commonly seen as a meningo-encephalitis, and this is the form encountered in this country. More controversially it has been cited as a cause of recurrent abortion (Seeliger \& Cherry, 1957; Rappaport et al., 1960), the latter reporting from Israel; MacNaughton (1962), however, in a series of seventyeight cases of abortion in Aberdeen found no evidence of listerial infection. It may also manifest itself as a septicaemic granulomatosis of neonates -the 'granulomatosis infantiseptica' of German writers.

The unusual case described here is a fatal adult infection.

\footnotetext{
*Formerly at Dulwich Hospital, London, S.E.22.
}

\section{Case report}

The patient was a West Indian female of 59 who had been in this country for 18 years. She was unmarried and lived by herself. Until about a year before her death she worked in a chocolate factory, but at that time she fractured her hip and was subsequently unable to work.

She was apparently well until 23 October, when she complained of nausea and frontal headache and became visually hallucinated. There was no contact with anyone with a similar complaint, nor had she any pets. She bought her milk from the same source as the rest of the house.

Her symptoms persisted, and on the 30 October she was admitted to the Maudsley Hospital as an emergency psychiatric patient. There she was found to be disorientated; her speech was incoherent, and she had a left facial palsy. It was felt that her symptoms had an organic basis and she was transferred to Dulwich Hospital on the same day. There she was conscious but confused; the abnormal physical findings were a subnormal temperature, slight jaundice, marked neck stiffness, a positive Kernig's sign, and a lower motor neurone palsy of her left facial nerve. She had bilateral lens opacities, but her fundi were normal. Lumbar puncture showed a turbid yellow fluid with a pressure of $70 \mathrm{~mm}$ of CSF, protein $1.8 \mathrm{~g} / 100 \mathrm{ml}$, cells $1200 / \mathrm{mm}^{3}$ (neutrophils) and glucose $18 \mathrm{mg} / 100 \mathrm{ml}$. Jugular compression produced no rise in CSF pressure.

An hour later she lost consciousness, and in view of the lumbar puncture findings, bilateral frontal burr holes were made (Mr P. J. Wilson). The pressure in the right lateral ventricle was normal, and clear CSF (protein $110 \mathrm{mg} / 100 \mathrm{ml}$ cells, $2 / \mathrm{mm}^{3}$ neutrophils) was obtained. The left ventricle was not entered. In the course of making the burr holes it was noticed that the subdural fluid was turbid and yellow, and at an increased pressure ; but the brain itself appeared at a normal tension. 
10,000 units of penicillin were injected into the right ventricle, and treatment with intramuscular penicillin (1 mega unit 6-hourly), intrathecal penicillin $(10,000$ units daily) and intravenous sulphadiazine ( $1 \mathrm{~g}$ 4-hourly) was started.

The following day culture of the CSF had produced a growth of Gram-positive rods. These were thought at first to be diphtheroid contaminants, but when Listeria was suspected the cultures were sent to the bacteriology department at King's College Hospital for animal inoculation where a positive guinea-pig eye test was obtained (Anton, 1934; Julianelle, 1941). The organism was partly sensitive to penicillin and fully sensitive to streptomycin and tetracycline, so intrathecal streptomycin (100 mg daily) was added to her penicillin, and sulphadiazine was discontinued.

For 3 days her level of consciousness improved, and on 3 November she could obey simple commands. Lumbar punctures continued to show no rise in CSF pressure on compression of her jugular veins, and the CSF protein remained very high (in the region of $2 \mathrm{~g} / 100 \mathrm{ml}$ ) though cisternal puncture showed only $225 \mathrm{mg}$ of protein. This, taken in conjunction with the Queckenstedt test, suggested that she had a spinal subarachnoid block. All the CSF specimens taken on these occasions were sterile.

Her temperature never rose above $95^{\circ}$ during this time, and she died 5 days after admission with the signs of broncho-pneumonia.

The results of other investigations were:

$\mathrm{Hb} 90 \%$ : WBC $13,000 / \mathrm{mm}^{3}$, later rising to 23,000 ; neutrophils $94 \%$; lymphocytes $3 \%$; monocytes $2 \%$; myelocytes $1 \%$.

The film on the second occasion showed occasional nucleated red cells in the presence of a neutrophil leucocytosis. There was a moderate amount of target cell formation and polychromasia, with a few macrocytes. These appearances, taken with the sickling of the red cells in all the histological sections (formalin fixed) suggest Haemoglobin $S$ trait.

Serum bilirubin $2 \cdot 25 \mathrm{mg} / 100 \mathrm{ml}$. Alk. Phosphatase $31 \mathrm{~K}$-A units.

L.A.P. 633 units (normal 150-350). Total serum proteins $7 \cdot 6 \mathrm{~g} / 100 \mathrm{ml}$.

Chest X-ray-normal. Blood culture showed no growth.

\section{Necropsy findings}

The body was that of a well-nourished coloured woman, with bilateral burr-holes in her skull. The brain showed a purulent meningitis affecting its upper and lower surfaces. These changes also involved the spinal cord, in the lower thoracic and lumbar regions. The dura was firmly adherent to the bodies of the cervical vertebrae. The only other organs with an abnormal appearance were the liver, which was a normal size but had coarse cirrhotic changes, and the lungs, which showed the signs of broncho-pneumonia.

Histology. The liver showed gross distortion of its architecture with surviving lobules and regenerating nodules separated by bands of fibrous tissue. The bile ducts were not conspicuous. There were numerous small scattered areas of leucocytic infiltration including many polymorphs, suggesting focal necrosis-otherwise there was moderate lymphocytic infiltration of the fibrous tissue. The latter also contained a number of small granulomata composed usually of one multinucleated giant cell, and rather elongated surrounding mononuclear cells. These granulomata were themselves often elongated; there was no caseation.

Apart from the granulomata, these appearances were consistent with post-necrotic cirrhosis.

The lungs showed broncho-pneumonic changes. Also visible were many multinucleate giant cells; these, unlike the giant cells seen in the liver, were not surrounded by a zone of mononuclear cells.

There was no caseation, and Ziehl-Neelson staining showed no tubercle bacilli.

The myocardium showed very slight fibrosis with occasional plasma cell and lymphocytic infiltration around the vessels.

In the spleen there was congestion of the pulp with scattered focal areas of interstitial fibrosis. The red cells were noticeably sickle shaped, both inside and outside vessels.

The kidneys showed only post-mortem changes.

Sections of the brain confirmed the purulent meningitis.

\section{Discussion}

Infection of animals with Listeria monocytogenes results in the formation of characteristic miliary granulomata and focal necrosis in the affected organs-the commonest of these being lung, liver and spleen. The typical granuloma consists of small round zones of wide meshed reticulum cells in which are embedded rather large pale mononuclear cells and nuclear debris. The latter is more frequently contained in the outer layers where polymorphonuclear cells and lymphocytes are found. More rarely the nodules contain giant cells of the Langhans type (Seeliger, 1961).

The patient described here was found to have granulomata and Langhans giant cells in her lungs and liver at post mortem. Since Listeria monocytogenes was isolated from her cerebrospinal fluid it is reasonable to suppose that these granulomata were, in fact, the result of a chronic Listerial infection preceding the meningitis by 
some time. The adult disease is said to be commoner in patients who are debilitated in some way - she was, in fact, recovering from a fractured hip at the time, and the post-mortem showed her to have a cirrhotic liver.

How she acquired the disease in the first place, and what processes might cause a chronic systemic infection to become a fatal meningitis, remains obscure. As far as we know this is the first adult case in British literature to show the granulomatous lesions characteristic of the disease.

\section{Summary}

The case is described of a 59-year-old West Indian woman who died of meningitis caused by Listeria monocytogenes. She was found at necropsy to have characteristic granulomatous lesions in her lungs and liver: it is suggested that she was suffering from chronic Listeriosis for some time before her meninges became infected by the organism.

\section{Acknowledgments}

We should like to thank Dr Clifford Hoyle for his advice and permission to publish details of the case, Professor
Cunliffe and the Bacteriology Department of King's College Hospital for their help in identifying the organism and H.M. Coroner for Southern District County of London for permission to publish details of the post-mortem examination.

\section{References}

Anton, W. (1934) Kritisch-experimenteller Beitrag zur Biologie des Bacterium Monocytogenes. Mit besondes Berucksichtigung seiner Beziehung zur Infectiosen Mononuklease des Menschen. Zbl. Bakt. (Orig.), 131, 89.

Julianelle, L.A. (1941) Biological and immunological studies of Listerella. J. Bact. 42, 367.

MacNaughton, M.C. (1962) Listeria monocytogenes in abortion. Lancet, ii, 484.

Murray, E.G.D., WebB, R.A. \& SwanN, M.B.R. (1926) A disease of rabbits characterised by a large mononuclear leucocytosis, caused by a hitherto underscribed bacillus Bacterium monocytogenes (n.sp.). J. Path. Bact. 29, 407.

Pirie, J.H.H. (1927) A new disease of veld rodents "Tiger River disease." S. Afr. Inst. med. Res. 3, 163.

RAPPAPORT, F., RABINOVITZ, M., TOAFF, R. \& Krochik, M. (1960) Genital Listerosis as a cause of repeated abortion. Lancet, i, 1273.

Seeliger, H.P.R. (1961) Listeriosis. Karger, Basel; Hafner, New York.

Seeliger, H.P.R. \& Cherry, W.B. (1957) Human Listeriosis. Its Nature and Diagnosis. U.S. Dept. H.E.W., C.D.C. Atlanta, Ga. 